\title{
Indicator of responsible consumption in hospitality companies: proposal of theoretical bases
}

\section{Indicador de consumo responsable en las empresas de hostelería: propuesta de bases teóricas}

\author{
DOI: $10.46932 / \mathrm{sfjdv2n3-055}$
}

Received in: May 1st, 2021

Accepted in: Jun 30th, 2021

\author{
Claudio Alexandre de Souza \\ Post doctaral in Université du Québec à Montréal - UQAM (Canada) \\ Universidade Estadual do Oeste do Paraná - UNIOESTE (Brasil) \\ Av. Tarquinio Joslin dos Santos, 1300, Foz do Iguaçu, Paraná, CEP 85.870-650, Brasil \\ E-mail: cas_tur@yahoo.com.br
}

\section{Zandra Balbinot}

Doctorate in International Management - HEC (Canada)

École des sciences de la gestion - ESG / Université du Québec à Montréal - UQAM (Canada)

315 St Catherine St E, Montreal, Quebec H2X 3X2, Canadá

E-mail: zbalbinot@gmail.com

\begin{abstract}
Studies indicate that there is demand for services performed responsibly. This study aims to present theoretical bases for the proposal of an indicator of responsible consumption for hospitality companies. It is the outcome of desk and documentary research on scientific bases for corporate social responsibility and sustainability indicators for hospitality companies. This research identifies the urgent need to review the way that corporate social responsibility actions are handled in this sector. It also identifies a need for change in the way that the social relationship with the client stakeholder is conceived from its inception. The research also confirms the importance of discovering different ways to act effectively towards sustainability. This study presents a theoretical proposal as a basis for Indicators of Responsible Consumption in Hospitality Companies (IRCHC). The specific goals of this research include: to present a theoretical proposal of IRCHC that adds value to CSs; to make sustainable the lifecycle of responsible service; to respect all sustainability dimensions; to have strategic applicability for HCs; and to be easily understood by involved parties.
\end{abstract}

Keywords: indicator, responsible consumption, hospitality companies.

\section{RESUMEN}

Los estudios indican que existe una demanda de servicios realizados de forma responsable. Este estudio tiene como objetivo presentar las bases teóricas para la propuesta de un indicador de consumo responsable para las empresas de hostelería. Es el resultado de una investigación documental y de gabinete sobre las bases científicas de los indicadores de responsabilidad social corporativa y de sostenibilidad para las empresas de hostelería. Esta investigación identifica la necesidad urgente de revisar la forma en que se gestionan las acciones de responsabilidad social corporativa en este sector. También identifica la necesidad de cambiar la forma en que se concibe la relación social con el cliente desde su inicio. La investigación también confirma la importancia de descubrir diferentes formas de actuar eficazmente hacia la sostenibilidad. Este estudio presenta una propuesta teórica como base para los Indicadores de Consumo Responsable en Empresas de Hostelería (IRCHC). Los objetivos 
específicos de esta investigación son: presentar una propuesta teórica de IRCHC que añada valor a las EF; hacer sostenible el ciclo de vida del servicio responsable; respetar todas las dimensiones de la sostenibilidad; tener aplicabilidad estratégica para las EF; y ser fácilmente comprensible para las partes implicadas.

Palabras clave: indicador, consumo responsable, empresas de hostelería.

\section{INTRODUCTION}

Studies indicate that there is demand for services performed in a sustainable manner. They also identify that there are hospitality companies (HCs) that develop responsible service projects. However, for many companies, their corporate social responsibility (CSR) actions do not translate into a financial return that enables their long-term viability. It is therefore necessary to understand how to reconcile the supply and demand of responsible services, and thereby harmonize the social relationship between HCs and consumer stakeholders (CSs) regarding responsible services.

To this end, this study presents a theoretical proposal as a basis for Indicators of Responsible Consumption in Hospitality Companies (IRCHC). The specific goals of this research include: to present a theoretical proposal of IRCHC that adds value to CSs; to make sustainable the lifecycle of responsible service; to respect all sustainability dimensions; to have strategic applicability for HCs; and to be easily understood by involved parties.

The increase in CSR and sustainability practices in the hospitality sector at a global level calls for further study (Font, Walmsley, Cogotti, McCombes \& Häusler, 2012; Fatma, Rahma \& Khan, 2016). Existing studies reveal areas of concern in this social relationship (Souza \& Alvares, 2014a, 2014b), but there is a lack of research into CSR and sustainability, mainly normalization, applied specifically to the hospitality sector to understand this dynamic (Camilleri, 2014, p. 42). A study carried out among consumer stakeholders discovered a perception that they are not consulted, but only informed, regarding what has already been done by the companies in the area of CSR and sustainability (Todero, Macke \& Biasuz, 2011). More studies are needed to establish what CSs understand, and how that aligns with the strategic goals of HCs.

The methodology for this theoretical study was carried out in six stages. First, we developed a state-of-the-art scientific study on concepts for understanding CSR and sustainability. Second, we performed a survey of the scientific research on indicators applied to HC. Third, we reviewed the state of the art of scientific studies on CSR and sustainability indicators. Fourth, we reviewed the scientific discussions on responsible consumption, and fifth, we analysed these studies. Finally, the theoretical bases applicable to the construction of an IRCHC were highlighted. 
This approach meets the guiding documents for the production of responsible tourism services worldwide, notably the Kerala Declaration on Responsible Tourism. This statement describes the need for a new way of doing business; for innovation to understand what CSs think about company actions; and for the possibility of co-creating actions of sustainability (The Kerala Declaration on Responsible Tourism, 2008, p.9). It makes use of systematic monitoring and measuring practices to understand what generates value for CSs (Ajzen, 2002).

CS behavior must be understood based on socio-demographic variables, using an instrument of data collection that also serves to sensitize them (Anderson Junior \& Cunningham, 1972). Any proposed indicators must study CSs by segment, to understand their perception of CSR and the sustainability practices of the HCs.

\footnotetext{
"This type of approach is what stakeholders want to see. As one of our respondents asserted, 'the organization shouldn't place itself first, because attention should be directed to the subjects under discussion.' The big idea here is simple: companies need to demonstrate their commitment to listening to stakeholders - and to pursuing an authentic and effective dialogue around CSR topics.” (Illia, Romenti \& Zyglidopoulos, 2015, p.5).
}

The background for the realization of this proposal comes from studies on recommendations to harmonize social relations of consumption between HCs and CSs (Cenci \& Burmann, 2013; Souza, 2016). The use of technology to understand the social relationship in a collectivity, with a transformative focus, requires changes in habits and attitudes, as well as a review of how to consume and produce, thereby building a proposal that adds value to all parties involved.

This project is developed in 5 parts. Part I presents a scientific analysis of the concepts and the relationship between CSR actions (long term) and sustainability. Part II develops an understanding of the consumption and production of responsible services. Part III analyses the practices and methodologies used as a basis for CSR and sustainability indicators. Part IV presents the methodological bases that support the proposal presented in this study. Part V presents theoretical bases for the IRCHC proposal, and is followed by some final considerations.

\section{FROM CORPORATE SOCIAL RESPONSIBILITY TO SUSTAINABILITY}

Discussions of the concept of CSR were first presented in the 1930s (Carrol, 1979). Some studies report that despite the considerable increase of companies that use CSR-related actions - and of research on this subject - there is still a need for further deepening (Commission of the European Communities, 2001); Font et al., 2012). For the purposes of this study, CSR is defined as:

"... integrated actions carried out by companies, aimed at stakeholders, with the purpose of making society a better place. Something voluntary that seeks a return to all parties involved in the action, 
even in financial terms, and may be in the long term, because they understand that companies are part of society, something beyond what is provided by law, regardless of the reason why they take action." (Souza, 2016, p.105)

Are CSR and sustainability synonymous or not? This is not the focus of the present discussion, but it is worth raising the question. Studies point out commonalities between these two concepts with regard to their operationalization at the enterprise level: to be voluntary; to extend beyond economic goals; and do more than what is required by law (Montiel, 2008; Perez-Batres, Miller \& Pisani, 2010; Font et $a l .$, 2012). In addition to presenting the concepts discussed here, alignment is proposed at both academic and marketing levels (Font et al., 2012), due to the strong relationship that both have with each other (Perez-Batres, Miller \& Pisani; 2010). For the purposes of this study, CSR actions are considered to be operational aspects developed by companies to reach their primary objectives and also achieve sustainability.

The CSR actions, in order to achieve their direct and indirect objectives, should be structured as processes with individual long-term goals. This perspective aims at achieving stability for the company's business, including harmonious social relations with all stakeholders (McDermott, 2009, p.292; Das Grupta, 2012, p.157). From a business perspective, CSR actions developed with long-term perspectives make it possible, beyond the reach of the stakeholders' objectives, to achieve sustainable development (McDermott, 2009, p.292; Sloan, Klingerberg \& Rider, 2013, p.19). This approach was also verified in a specific study of the hospitality sector and the connection between CSR actions and sustainability, and the need to implement practices with long-term processes, as opposed to the usual short-term practices for immediate profit (Camilleri, 2014, pp.42-28). Understanding this perspective means that companies and all stakeholders are favorably positioned for socio-environmentally responsible management practices.

In order for the direct and indirect goals of CSR actions to be achieved, it is necessary for stakeholders to understand what these actions are. Even in situations where companies have effective CSR strategies, stakeholders do not recognize what companies do (Costa \& Menichini, 2013, p.151). This raises the question of how to communicate with stakeholders about the CSR actions carried out (Costa \& Menichini, 2013, p.158), (Souza \& Alvares, 2014a). It is understood that some stakeholders expect CSR action, and that non-occurrence engenders negative feedback (McWilliams \& Siegel, 2011, p.1492). Having some action, or even inaction, on CSR in itself communicates a message to stakeholders. Managing the communication of these CSR actions is something that must be prioritized to achieve the desired objectives.

Understanding the CSs is necessary for companies to integrate CSR actions (Heslin \& Ochoa, 2008, p.130; Font et al., 2012, p.1544), but it is not necessary to wait for them to demand CSR actions: 
companies can be proactive and anticipate this demand (Back, 2015, p.28). Thus, CSs are given an understanding of what CSR actions are, how they work, and how they can best be developed (Font et al., 2012). This type of CSR action appeals to customers seeking a responsible socio-environmental lifestyle (Heslin \& Ochoa, 2008, p.133). These actions also make it possible to increase demand from new consumers by contributing to the education of these CSs (McDermott, 2009, p.293). Such practices can provide the formation of CS's with a propensity towards loyalty, based on the perception of a good reputation (Costa \& Menichini, 2013, p.150). This applies to micro and small enterprises, traditionally excluded from the processes when it comes to CSR (Back, 2015, p.47).

The CSR actions are the result of a harmonious social relationship between HCs and CSs. CSR should not be seen as an action to forestall punishment, or as an atonement of guilt (Back, 2015, p.49). It should be understood as a result of the experiences between an HC and CSs, making the company unique and difficult to imitate by providing differentiated and striking experiences for its customers (Heslin \& Ochoa, 2008; Camilleri, 2014, p.47; Souza, Soares \& Fernández, 2016). CSR actions should be understood as an initiative that will provide an engaging and educative experience.

\section{SOCIAL RELATIONSHIP OF RESPONSIBLE CONSUMPTION}

In the last century, a series of events raised the environmental theme to a level of world importance, addressing the need for social indicators to understand the CSs opinions on the subject (Fisk, 1973, p.31). However, it has been posited that CSs are just one of the elements entangled in the web that involves the economy as a whole and cannot be held solely responsible for the planet's environmental problems (Sanne, 2002). It is known that there is a strong relationship between the planet's limited resources and consumption (Beck, 2010, p.16); studies have shown that both researchers, governments, and companies are concerned that consumption causes impact not supported by the planet (Barotin \& Retondar, 2010, p.3). However, blame can not be assigned to only one of the stakeholders, since the problem, as well as the means of solving it, involves integration among all parties.

In order to achieve sustainability, CSR actions must be developed with a long-term focus, and through activities that apply to both production and consumption in a synergistic way (Furriela, 2001). This includes responsible consumer action as a collective and long-term interest (Beck, 2010, p.16). It is considered long-term, since this type of change in CS is a behavior change, and changes of this nature tend to be long-term in order to consolidate in the behavior of the collective (Silva, Santos \& Araujo, 2012). Understanding that these cultural changes result from a long-term process is to understand that this is the time needed for behavior change and so-called sustainability (Mihalic, 2016). This practice is possible, however, as a result of synergistic actions that provoke alteration in a collective behavior. 
In order to engage CSs, it has been argued that co-operative actions aim at achieving the goals of each party involved (Marchand \& Walker, 2008, p. 1168). In the HC industry, the existence of a new segment, such as online companies, enables new means of carrying out CSR actions and integrating stakeholders (Venu \& Goodwin, 2008, p.8). This makes these CSR actions a natural part of the social relations among stakeholders (François-Lecompte, 2009, p.92), and CSR actions that do not encumber them are developed as a result (Barotin \& Retondar, 2010). Production and consumption are the basic forces that move the companies, exhibiting an interdependent relationship that needs to be rethought from its inception (Gonçalves-Dias \& Teodósio, 2012). A proposal for achieving sustainability must be pursued in an integrated manner between production and consumption, with the stakeholders involved in each analyzed social relationship (Cenci \& Burmann, 2013; Illia, Romenti \& Zyglidopoulos, 2015, p.3-5).

Studies have already identified the relationship between increased knowledge on the part of CSs and the increased consumption potential from companies with CSR actions (Wigley, 2008). It has been observed that CSs behave responsibly in their consumption not only because they are more aware of CSR actions, but also because they identify the benefits that the product or service adds to them (Marchand \& Walker, 2008). It was found that customers' beliefs and concerns were the motivations that changed their behavior (Schultz, 2001; Hansla et al., 2008; Beck, 2010, p.64). CSs with responsible behavior understand the benefits of CSR actions, including that they benefit companies as well, thus seeking transparency in information for their respective decision-making on their consumption (Yi, Li \& Jai, 2016).

The responsible CSs want to see CSR actions in all dimensions, integrated with native communities and promoting unique experiences (Wehrli, Egli, Lutzenberger, Pfister, Schwarz \& Stettler, 2012, p. 223). They demand that instead of placing more emphasis on marketing their actions, companies must invest in the act of making CSR actions integrated and focused on stakeholders, reducing or eliminating the need to spend on marketing (Illia, Romenti \& Zyglidopoulos, 2015). However, it remains to be studied whether companies understand the CSs with this level of perception on the subject.

Social relations between HCs and CSs should always be harmonious and symmetrical, with content and consistency. The product or service must be considered good in all respects, from the first contact to after-sales, regardless of whether the company performs CSR actions or not (Beckmann, 2007, p.31). A company that wishes to responsibly serve CSs must offer something that promotes an authentically human contribution to the proposed social relation of consumption (Ozcaglar-Toulouse, 2009). However, it has been observed that few companies deliver something consistent to their CSs (Beck, 2010, p.48), something that promotes an individualization of the tangible and effective consumption experience that demonstrates in loco commitment (Nielsen, 2014; Barber, 2014, p.380). Actions must be fair, respectful, honest, and appropriate to the interests of the CSs to give results (Nielsen, 2014). However, 
it is necessary that companies develop products for specific markets, and not generically, if they want to connect with their CSs (Barber, 2014, p.363; Illia, Romenti \& Zyglidopoulos, 2015). A CS connects with the company by realizing that the outcome of the social relationship is solid and beneficial to all.

A way of producing that allows the CS to see, participate, learn, and understand the actions performed increases CS knowledge (Portilho, 2005; Wigley, 2008; Gonçalves-Dias \& Teodósio, 2012). Marketing techniques already adopted in relation to production and consumption are used, promoting an integrated social relationship among stakeholders with a focus on sustainability (Beck, 2010, p. 50; Cenci \& Burmann, 2013; Illia, Romenti \& Zyglidopoulos, 2015, pp.3-5). This results in business practices that will not need to specifically disclose CSR actions, because doing so will be integrated in the existing communication activity.

It is necessary for businesses to know, understand, and communicate to consumers actions that are of interest to them (Nielsen, 2014). After all, many CSs still do not understand CSR actions when these are communicated poorly (De Toni, Larentis, Mattia, Gilioli \& Milan, 2013, p. 17). Many companies have communicated their actions based on a perception that CSs are skeptical of whether CSR actions are always done honestly, leading companies to be unsure whether to communicate or not (Becker-Olsena, Cudmoreb \& Hill, 2006; François-Lecompte, 2009, p. 91). That said, many businesses propose a dialogue with CSs to get to know them and have them commit to the company's CSR actions, so that they are part of the production process (Mihalic, 2016). In this way, instead of investing resources to publicize something done to see if it is in the interest of CSs, resources will be invested in integrating them to be committed to the CSR action, minimizing or dissolving discrepancies in the perspectives of different stakeholders (Yi, Li \& Jai, 2016, p. 9). Thus, social relations of CSR will be the result of integrated action with stakeholders, and communication is an integral part throughout the social relationship and not a final moment of it.

For this purpose, consumption is proposed that is good for CSs, and which will be co-produced in a way that is responsible for all parties involved (Portilho, 2005). It was also identified that CSs would like to be involved in corporate CSR projects (Becker-Olsena, Cudmoreb \& Hill, 2006, p. 52); such a position meets the need for co-produced CSR actions (Marchand \& Walker, 2008, p. 1168). Responsible CSs are more active; that is the reason why there is a need to participate and demonstrate the CSR action (Monteiro, Veiga, Maercio \& Goncalves, 2008, p.46). But in order to achieve this there is a need for the active participation of CSs as co-operative agents, with critical and demanding attitudes (Beck, 2010, p. 51). In this manner the company can demonstrate that the CSR action does exist, and show how it was developed (Silva, Ribeiro \& Reiz, 2012); as consequence, the CSs have unique and differentiated experiences (Nielsen, 2014; Illia, Romenti \& Zyglidopoulos, 2015, pp.3-5). Developing CSR action 
strategies to integrate the social relationship of production and consumption will provide a change of attitude, resulting in commitment by CSs.

\section{BACKGROUND FOR CSR OR SUSTAINABILITY INDICATORS}

Several studies have presented documents that are used as a basis for CSR or sustainability indicators, as listed in Box 1. This study's purpose is not to exhaust such bases, because some previous studies have mentioned the existence of hundreds of documents like these, in several parts of the world. This study represents only a random sample of the diversity of existing documents used for the purpose proposed here.

One approach that has been questioned is the lack of relationships with all stakeholders (de Leaniz $\&$ del Bosque, 2013, p.53). Some studies do not make it clear which stakeholder is involved in the social relationship, or to which stakeholders the indicators refer (De Felice, 2015). Since CSR actions take place among stakeholders involved in social relations, it is also required that their perspectives should be included (Montuschi, 2010), and how they are affected should be taken into account (Schäfer, 2005, p.115). This occurs because in several studies the indicators used included only few stakeholders (Alzate \& Hincapié, 2010, p.8). These aspects result in many documents selected to create indicators which only reflect the interests of the companies. In other words, the indicator does not identify respect for the stakeholders of the respective social relationship.

The sustainability-conscious CS behaves in a favorable way to HCs with CSR practices (Oliveira, Silva \& Gómez, 2012). Some variables promoted by CSR practices, such as those related to the community and the environment of the visited space, directly contribute to CS satisfaction (Bonilla \& Bonilla, 2007). In this way, some studies come to understand how the structure of consumer satisfaction is given (Al-Nasser, 2003, pp. 214-215). Satisfying CSs is condition sine qua non for the existence of the company, so understanding them becomes increasingly necessary in terms of competitiveness.

CS have positioned themselves favorably to consume from companies with CSR actions (Lee \& Shin, 2010, p.194). This already directs each company to try and understand even more sociodemographic information about their respective responsible CSs (Barber, 2014, p.369), and in turn, to understand the preferences of services and products offered and respective purchasing behavior of responsible CSs (Barber, 2014, p.370). This is so that HCs can understand the purchasing potential related to the positioning of the company (Garbarino \& Johnson, 1999). That is, companies should seek to know socio-demographic data and preferences so that they can develop actions aligned with the objectives of the responsible CSs involved in the social relation of consumption (Souza, 2016). 
There is a need to implement CSR actions in meaningful social relationships with CSs. Companies must create proactive, not reactive, CSR actions that are not a response to a demand imposed on the company, but which are created to meet their own goals as well as CS goals (Pachi \& Arbex, 2007, p.36). Proactive actions also contribute to awaken favorable attitudes by CSs (Becker-Olsen, Cudmore \& Hill, 2006). However, such behavior was only identified in CSs with a certain level of consciousness about sustainability and CSR, which is manifests in both their daily behavior and their tourism activities (Servaes \& Tamayo, 2013, p.1058). This condition allows them to identify and understand the experience provided by the performed action as a differential, considered personal and involving, identifying the moment as something beyond good service, even as an emotional link through shared goals (Gentile, Spiller \& Noci, 2007). CSs assign due value to the action of proactive CSR because they are sufficiently aware of its content to understand the experience that will be allied to the service acquired.

CSs have the power to value CSR actions to which they are parties or have access. Some studies have identified CSs who report that CSR actions influence them positively, including their consumption habits (McWilliams \& Siegel, 2011, p.1492). However, they also affirm that some actions of CSR, despite being perceived, are not understood (McWilliams \& Siegel, 2011, p.1492). In other cases, CSs discern between CSR actions perceived as positive and negative, and behave proportionally (Servaes \& Tamayo, 2013, p.1058). In this way, the need to carry out CSR actions aligned with stakeholders' goals is emphasized (Becker-Olsen, Cudmore \& Hill, 2006, p. 46). Synergistic results are sought for CSs. They must be an integral part of the CSR action, so that its objectives can be contemplated from its inception.

\section{THEORETICAL BASIS FOR AN IRCHC}

The IRCHC is a proposed indicator that provides understanding about CS perception of the CSR actions performed by HCs. It aims to contribute to HCs, so that each company can have data to execute its respective CSR actions appropriate to its social relationship with the target CSs.

In this paper, the usual form of CSR social relation between HC and CS is called "CSR traditional social relation" or simply "traditional". One of the characteristics of this traditional form is the fact that HCs elaborate CSR actions according to their preferred strategic actions. The way in which HCs communicate with CSs about traditional CSR actions is usually through the communication of results. IRCHC starts from the principle of creating knowledge for value generation. This proposal shifts the logic from communicating what was done, to calling to act together; from communication to co-creation, as seen in Figure 1.

Figure 1 - Communication process of CSR actions from HC to CS (Top-Down) 


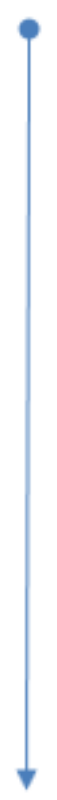

Hospitality Companies

CSR Actions

Consumer Stakeholders

Source: own authorship, 2017.

The traditional form of the social relationship between the HC and CS is through communication from the former to the latter. HCs decide what to do and why, and only communicate the final results to CSs after the implementation of CSR actions. In this new proposal, the bases on which actions develop originate from both HCs and CSs. Consequently, communication exists to engage CSs throughout the cocreation process. 
Figure 2 - Harmonic perceptions for co-creation of CSR actions

Harmonic perceptions for co-creation of CSR actions

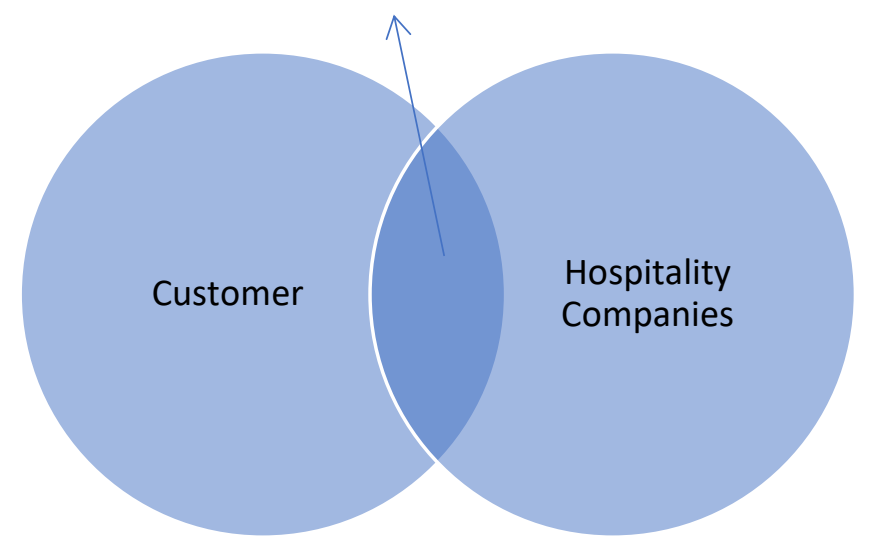

Source: own authorship, 2017.

As result of this proposal, it is possible to develop actions that are of interest to both parties involved in the process from its inception. It transforms the existing social relationship into a harmonious one, as seen in Figure 2. This harmony in turn makes the social relationship beneficial to all parties involved in the process. It generates value for both, as result of serving both parties' interests from the start, and creates actions that meet the goals of all parties involved in the process, as seen in Figure 3.

Figure 3 - Process of usage of IRCHC and co-creation of CSR actions

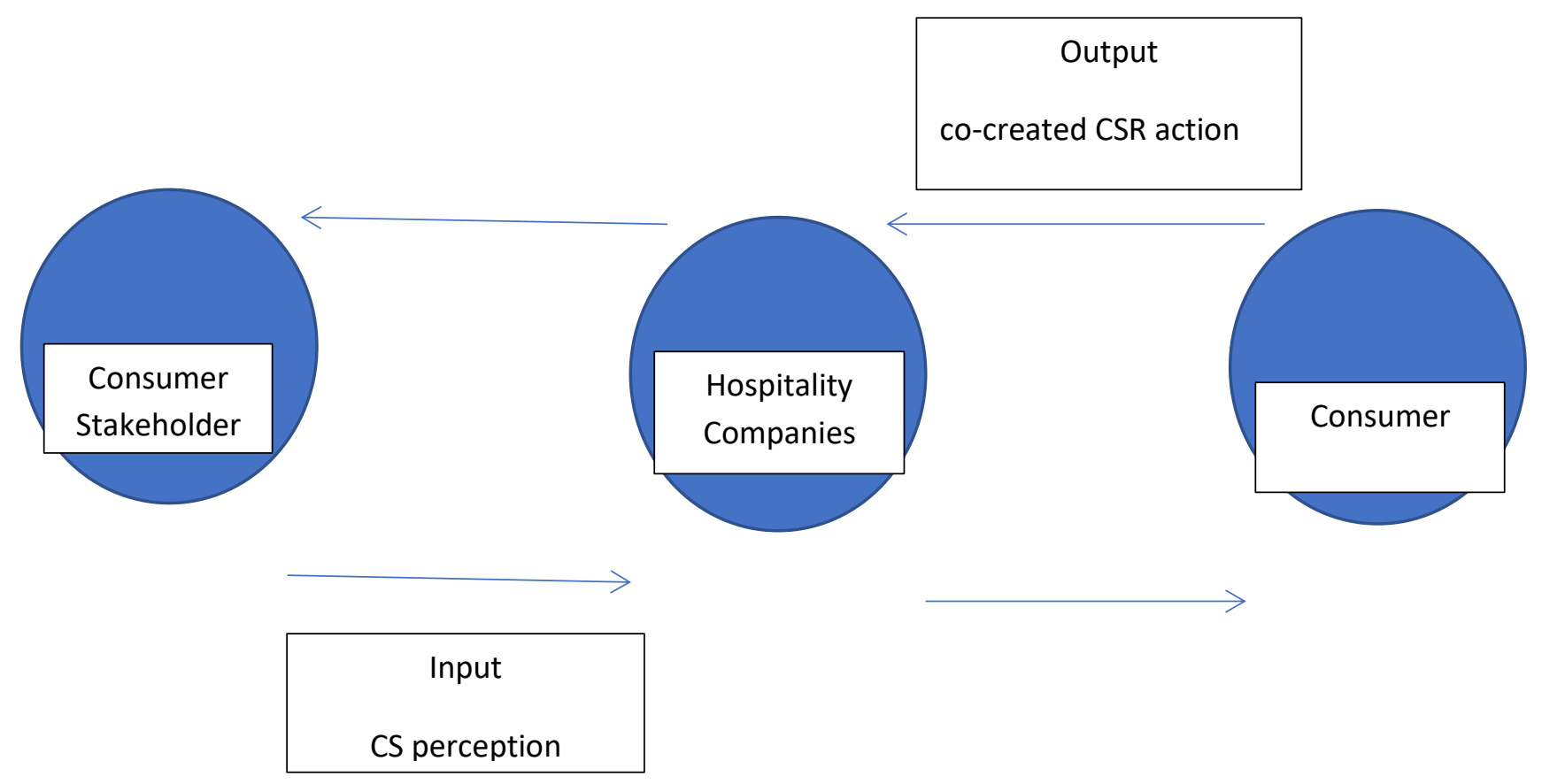

Source: own authorship, 2017. 
This new proposal is no longer merely the result of the interest of one of the parties, but rather is the result of interaction between the parties. IRCHC is the result of the application of research with CSs to understand their perception. Based on IRCHC, HCs align their interests in CSR actions to the CSs interests. CSR actions co-created based on the interest of the parties will then follow from this alignment. Following this process will allow other CSs to live this experience in loco. This fact will result in continuous research with other CSs who have informed their perception from this new experience, culminating in a process that feeds information continuously. Thus, CSs are involved in all parts of the process: before, during, and after CSR actions, as seen in Figure 4.

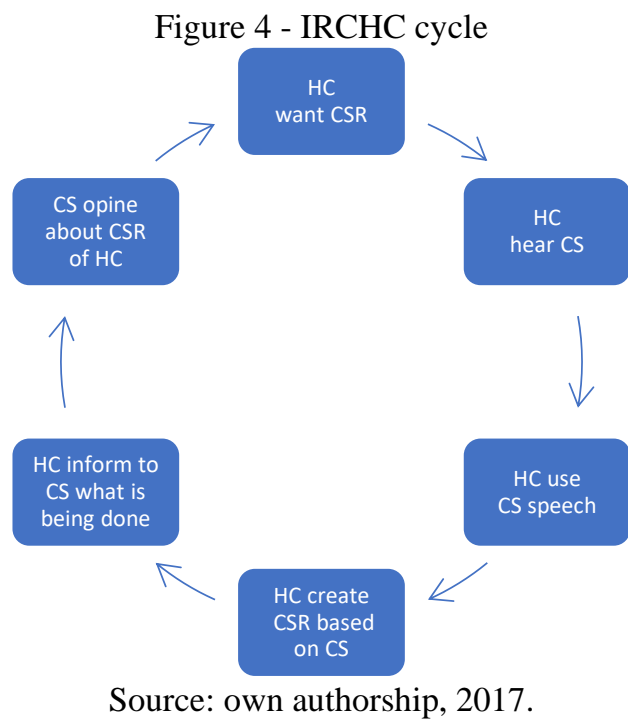

Next, the IRCHC is presented together with a comparative analysis with the traditional way of carrying out CSR actions. This will serve to clarify the value that IRCHC adds in relation to the traditional form, presented in blocks of content. It is also emphasized that the theoretical basis for this comparative analysis is presented in the aforementioned study.

It is necessary to readjust the bases that give rise to the data that guide the existing CSR indicators. This is a key change: to consider the result of IRCHC for the creation of CSR action before starting it, and thereby adding value to both HCs and CSs.

In the traditional method, CSs are communicated to only after actions have taken place, since in this proposal the companies studied are HCs, for whom it is uniquely necessary to have the CS literally move into their physical space. This proposal aims to respect this uniqueness. Once customers enter an HC's space, they can see or coexist with the CSR action in loco. In this way, the possibility of CS participation is consolidated before, during, and after the implementation of CSR actions.

They need to be understood, so that they have meaning for the CSs. Data need to be clear to all those for whom they must generate values: their reading must be understandable, since CSs will 
experience a moment within the HC. To generate value for all involved parties, IRCHC has to be a result of the interest and purpose of them all. It has to be accessible to all parties involved, so that they understand its origin and its importance. In order for the indicator to reflect the perception of the parties involved, it must have variables coming from them all.

It is emphasized that CSs are living beings, with changeable positions, as are the individuals that compose the HCs. Therefore, it is necessary to develop a methodology that is periodically applied, so it can capture the changes that occur, thereby enabling it to evolve continuously. IRCHC will understand what the CS believes should be performed and analyzed.

\section{CONCLUDING REMARKS}

The market has sought for several years to regulate the social relation of consumption and production. This IRCHC proposal presents a possible landmark for such a search, since it understands the CS perspective on responsible consumption of an HC. This indicator enables the development of harmonious social relations between the parties involved, developing a possible scenario to create social relations of consumption directed toward sustainability.

This study also contributes to the expansion of the theoretical discussion and proposes a technical tool to know more about the social relations between HCs and their respective CSs. The theoretical discussion showed that there are still gaps that need to be understood in this social relation. However, the theoretical and practical perspectives complement each other, making possible the construction and validation, followed by the respective continuous increase, of the knowledge in this area of study.

However, it presents the need for an evolution if it is still used as a basis for the creation of indicators, due to the natural changes in society, and the ever-increasing rate of these changes. The proposed tool aims to continuously and practically contemplate this connection between HCs and CSs. A tool with this characteristic is needed so that the basis for construction of CSR actions is shared among those involved, and no longer unilaterally realized as it has been traditionally treated.

We must think about how to use technology to improve the social relationship between humans and the basis for disruptive ideas and understand the need to innovate and create new mechanisms of connection between stakeholders and a basis for actions that meet the objectives of all those involved. In this way, the social relation of production and consumption in disruptive hospitality companies must be understood.

There is still much to be studied in the areas of sustainability, CSR, and responsible consumption. It is necessary to understand the ideal form of the social relation of consumption; how responsible consumption can contribute to improving socio-environmentally responsible production; and how the 
social relation of responsible consumption and socio-environmentally responsible production between HCs and CSs can contribute to the achievement of sustainability.

Based on the literature, we recommended a better integration between HCs and researchers for the development of more studies in a systemic, punctual, and regular way. HCs have been developing many projects in the last decades in search of sustainability, but the absence of data and studies limits understanding of what is happening. A partnership between HCs and study centers will enable the goals of both parties to be addressed.

Understanding the social relations and the parts that make it up is a sine qua non condition for reaching the stakeholders' goals. Having a harmonious social relationship between the parties is a basic aspect for sustainability to be achieved as a result of social relations among stakeholders. Knowledge applied and disseminated in a clear and transparent way between the parties will enable actions to be developed that are sustainable, by seeking common results for all parties involved.

\section{ACKNOWLEDGMENTS}

The authors are grateful for the support offered by the Transat Chair in Tourism of the School of Management of the University of Quebec in Montreal (ESG-UQAM). 


\section{REFERENCES}

Ajzen, I. (2002). Constructing a TPB questionnaire: conceptual and methodological considerations.

Al-Nasser, A. (2003). Customer satisfaction measurement models: generalised maximum entropy approach. Pakistan journal of statistics-all series, 19(2), 213-226.

Alzate, C., \& Hincapié, L. (2010). Estandarización de indicadores de responsabilidad social empresarial propuestas por organizaciones de reconocimiento mundial (Master's thesis, Pereira: Universidad Tecnológica de Pereira).

Anderson Junior, W., \& Cunningham, W. (1972). The socially conscious consumer. Journal of Marketing, 36(3), 23-31

Back, L. (2015). Responsabilidade social corporativa em empresas de pequeno e médio porte: fatores que influenciam a adoção de iniciativas de sustentabilidade. Master's Thesis, Pontifícia Universidade Católica do Rio Grande do Sul, Porto Alegre, RS, Brasil.

Barber, N. (2014). Profiling the potential "green" hotel guest: who are they and what do they want? Journal of Hospitality \& Tourism Research, 38(3), 361-387.

Beck, C. (2010) Consumo ambientalmene consciente: os meus, os seus e os nossos interesses. Master's thesis, Universidade Federal da Paraiba. Joao Pesoa, PB, Brasil.

Becker-Olsen, K., Cudmore, B., \& Hill, R. (2006). The impact of perceived corporate social responsibility on consumer behavior. Journal of Business Research, 59(1), 46-53.

Beckmann, S. (2007). Consumers and corporate social responsibility: matching the unmatchable? Australasian Marketing Journal, 15 (1), 27-36.

Bonilla, J., \& Bonilla, L. (2007). La capacidad de carga psicológica del turista como indicador del turismo sostenible. Boletín ICE económico, (2911), 25-35.

Camilleri, M. (2014). Advancing the sustainable tourism agenda through strategic perspectives. Tourism Planning \& Development, 11(1), 42-56.

Comission of European Communities. (2001). Green Paper. Brussels: Authors.

Costa, R., \& Menichini, T. (2013). A multidimensional approach for CSR assessment: the importance of the stakeholder perception. Expert Systems with Applications, 40(1), 150-161.

De Felice, D. (2015). Business and human rights indicators to measure the corporate responsibility to respect: challenges and opportunities. Human Rights Quarterly, 37(2), 511-555.

De Toni, D., Larentis, F., Mattia, A., Gilioli, R., \& Milan, G. (2013). Consumo consciente e seus impactos sobre valor percebido e lealdade em produtos ecologicamente corretos: proposição e teste de um modelo teórico. Revista Gestão Organizacional, 6(2), 4-20.

Fatma, M., Rahman, Z., \& Khan, I. (2016). Measuring consumer perception of CSR in tourism industry: scale development and validation. Journal of Hospitality and Tourism Management, 27, 39-48. 
Fisk, G. (1973). Criteria for a theory of responsible consumption. Journal of Marketing, 37(2), 24-31.

Font, X., Walmsley, A., Cogotti, S., McCombes, L., \& Häusler, N. (2012). Corporate social responsibility: the disclosure-performance gap. Tourism Management, 33(6), 1544-1553.

François-Lecompte, A. (2009). La consommation socialement responsable: oui mai. Reflets et perspectives de la vie économique, 48(4), 89-98.

Furriela, R. (2001). Educação para o consumo sustentável. In: Ciclo de palestras sobre meio ambiente (47-56) Brasilia: SEF/MEC.

Gentile, C., Spiller, N., \& Noci, G. (2007). How to sustain the customer experience: an overview of experience components that co-create value with the customer. European Management Journal, 25(5), 395-410.

Gjølberg, M. (2009). Measuring the immeasurable? Constructing an index of CSR practices and CSR performance in 20 countries. Scandinavian Journal of Management, 25(1), 10-22.

Gonçalves-Dias, S. \& Teodósio, A. (2012). Controvérsias em torno do consumo e da sustentabilidade: uma análise exploratória da literatura. Amazon, Organizations and Sustainability, 1(2), 61-77.

Illia, L., Romenti, S., \& Zyglidopoulos, S. (2015). Creating effective dialogue about corporate social responsibility. MIT Sloan Management Review, 57(1), 1-6.

Lee, K., \& Shin, D. (2010). Consumers' responses to CSR activities: the linkage between increased awareness and purchase intention. Public Relations Review, 36(2), 193-195.

Marchand, A., \& Walker, S. (2008). Product development and responsible consumption: designing alternatives for sustainable lifestyles. Journal of Cleaner Production, 16(11), 1163-1169.

McDermott, C. (2009). Corporate Agenda 21: a unified global approach to CSR and sustainability. Corporate Communications: An International Journal, 14(3), 286-302.

McWilliams, A., \& Siegel, D. (2011). Creating and capturing value: Strategic corporate social responsibility, resource-based theory, and sustainable competitive advantage. Journal of Management, 37(5), 1480-1495.

Mihalic, T. (2016). Sustainable-responsible tourism discourse e towards 'responsustable' tourism. Journal of Cleaner Production, 111 (1), 461-470.

Monteiro, P., Veiga, R., Márcio, M., \& Gonçalves, A. (2008). Personalidade e consumo ecologicamente consciente. Faces Revista. Administracao, 7(2), 30-49.

Montiel, I. (2008). Corporate social responsibility and corporate sustainability separate pasts, common futures. Organization \& Environment, 21(3), 245-269.

Montuschi, L. (2010). Desarrollos recientos en los instrumentos para integrar la RSE a las operatorias de las empresas (No. 439). Serie Documentos de Trabajo, Universidad del CEMA: Área: negocios. 
Nielsen. (2014). Doing well by doing good. Available at: http://www.nielsen.com/us/en/insights/reports/2014/doing-well-by-doing-good.html. Access in November, 2017.

Ozcaglar-Toulouse, N. (2009). What meaning do responsibe consumer give to their consumption? an approach by narratives. Recherche et Applications en Marketing, 24(3). p. 3-22.

Oliveira, A., Silva, M., \& Gómez, C. (2012). Indicadores de consumo consciente: uma avaliação do recifense sob a ótica do consumo sustentável. Simpósio de Administração da Produção, Logística e Operações Internacionais (SIMPOI), 15.

Pachi, F., \& Arbex, N. (2007). Conceptos básicos e indicadores de responsabilidad social empresarial. Bogotá, Pontificia Universidad Javeriana, Facultad de Comunicación y Lenguaje.

Perez-Batres, L., Miller, V., \& Pisani, M. (2010). CSR, sustainability and the meaning of global reporting for Latin American corporations. Journal of Business Ethics, 91(1), 193-209.

Portilho, F. (2005). Consumo sustentável: limites e possibilidades de ambientalização e politização das práticas de consumo. Cadernos EBAPE, 1(1), 1-12.

Sanne, C. (2002). Willing consumers - or locked-in? Policies for a sustainable consumption. Ecological Economics, 42 (1), 273-287.

Schäfer, H. (2005). International corporate social responsibility rating systems: conceptual outline and empirical results. Journal of Corporate Citizenship, 20(1), 107-120.

Servaes, H., \& Tamayo, A. (2013). The impact of corporate social responsibility on firm value: The role of customer awareness. Management Science, 59(5), 1045-1061.

Silva, M., Ribeiro, T., \& Reiz, C. (2012). O consumo consciente como fator determinante para a propagação da sustentabilidade na sociedade. Revista de Administração da Fatea, 5(5), 109-124.

Silva, M., de Oliveira, A., \& Gómez, C. R. P. (2013). Indicadores de consumo consciente: uma avaliação do recifense sob a ótica do consumo sustentável. Revista Eletrônica de Ciência Administrativa, 12(2), 3956.

Sloan, K., Klingenberg, B., \& Rider, C. (2013). Towards sustainability: examining the drivers and change process within SMEs. Journal of Management and Sustainability, 3(2), 19-30.

Souza, C. (2016). "DNA" da responsabilidade social empresarial. Revista Direito à Sustentabilidade, 2(4), 102-113.

Souza, C., \& Alvares, R. (2014a). A percepcão do cliente dos meios de hospedagens pioneiros na certificação sustentável no Brasil: NBR 15401:2006. Revista Turismo-Estudos \& Práticas, 3(2), 60-76.

Souza, C., \& Alvares, R. (2014b). Certificação sustentável em meios de hospedagem: Caso da certificação NBR 15401 no Brasil. Rosa dos Ventos - Turismo e Hospitalidade, 6(4), 531-545.

Souza, C., Soares, J., \& Fernández, M. (2016). Motivaciones para acciones de RSE en resorts en Brasil. Revista de Estudios Empresariales. 2(1), 32-54. 
Venu, V., \& Goodwin, H. (2008). The Kerala Declaration on Responsible Tourism. In: Incredible India, Second International Conference on Responsible Tourism in Destinations, Kerala.

Wehrli, R., Egli, H., Lutzenberger, M., Pfister, D., Schwarz, J., \& Stettler, J. (2012). Tourist's understanding of sustainable tourism: an analysis in eight countries. GSTF - Journal on Business Review (GBR), 2(2), 219-224.

Wigley, S. (2008). Gauging consumers responses to CSR activities: does increased awareness make cents? Public Relations Review, 34 (1), 306-308.

Yi, S., Li, X., \& Jai, T. (2016). Hotel guests' perception of best green practices: a content analysis of online reviews. Tourism and Hospitality Research. 0(0), 1-12. 